\title{
Chronic diseases, multimorbidity, and handgrip strength among older adults from Southern Brazil
}

\section{Doenças crônicas, multimorbidade e força de preensão manual em idosos de uma}

\section{comunidade do Sul do Brasil}

Júlia PESSINI ${ }^{1}$

Aline Rodrigues BARBOSA²

Erasmo Benício Santos de Moraes TRINDADE ${ }^{3}$

\section{A B S T R A C T}

\section{Objective}

To investigate the association between various chronic diseases, multimorbidity, and handgrip strength in community dwelling older adults in Southern Brazil.

\section{Methods}

A cross-sectional study carried out with 477 older adults (60 years and older) who resided in Antônio Carlos, Santa Catarina state. Subjects aged $60-79$ years were selected by probability sampling $(n=343)$ and all subjects aged 80 years or older $(n=134)$ were evaluated. Chronic diseases were identified by self-report. A mechanical dynamometer verified handgrip strength (i.e., the outcome). Adjustments variables were age, literacy, living arrangement, smoking, body mass index, cognitive function, and comorbid chronic diseases. Sex-stratified analyses were conducted with simple and multiple linear regression.

\section{Results}

A total of 270 women (73.2 \pm 8.8 years) and 207 men (73.3 \pm 9.0 years) were assessed. In the adjustment analysis, cancer $(\beta=-3.69 ; 95 \% \mathrm{Cl}=-6.97$ to -0.41$)$ and depression $(\beta=-1.65 ; 95 \% \mathrm{Cl}=-3.20$ to -0.10$)$ were associated with lower handgrip strength in women. For men, diabetes $(\beta=-5.30 ; 95 \% \mathrm{Cl}=-9.64$ to -0.95$)$, chronic lung disease $(\beta=-4.74 ; 95 \% \mathrm{Cl}=-7.98$ to -1.50$)$, and coronary heart disease $(\beta=-3.07 ; 95 \% \mathrm{Cl}=-5.98$ to -0.16$)$ were

\footnotetext{
1 Universidade Federal de Santa Catarina, Centro de Ciências da Saúde, Programa de Pós-Graduação em Nutrição. Florianópolis, SC, Brasil.

2 Universidade Federal de Santa Catarina, Centro de Desportos, Departamento de Educação Física. Campus Reitor João David Ferreira Lima, 88040-900, Florianópolis,SC, Brasil. Correspondência para/Correspondence to: AR BARBOSA. E-mails: <aline.r.barbosa@ufsc.br>; <alinerb13@yahoo.com.br>.

3 Universidade Federal de Santa Catarina, Centro de Ciências da Saúde, Departamento de Nutrição. Florianópolis, SC, Brasil. Support: Conselho Nacional de Desenvolvimento Científico e Tecnológico (Process no 478073/2009-7).
} 
associated with lower handgrip strength values. There was an inverse trend between number of diseases and handgrip strength for men only.

\section{Conclusion}

The results showed an independent association between chronic diseases and handgrip strength. As such, handgrip strength is a valid measure to use for prevention or intervention in chronic disease and multimorbidity.

Keywords: Aging. Chronic disease. Hand strength.

\section{R E S U M O}

\section{Objetivo}

Analisar associação entre doenças crônicas, multimorbidade e força de preensão manual em idosos de uma comunidade do Sul do Brasil.

\section{Métodos}

Estudo epidemiológico, transversal, de base populacional e domiciliar, realizado com 477 indivíduos com idade a partir de 60 anos, residentes em Antônio Carlos, Santa Catarina. Os idosos de 60 a 79 anos foram selecionados por amostragem probabilistica $(n=343)$, e todos os individuos com 80 anos ou mais $(n=134)$ foram avaliados. As doenças crônicas foram identificadas por autorrelato. A força de preensão manual (desfecho) foi mensurada por meio de dinamômetro mecânico. As variáveis de ajuste foram idade, escolaridade, arranjo familiar, tabagismo, índice de massa corporal, estado cognitivo e doenças crônicas. As análises, estratificadas por sexo, foram realizadas por meio de regressão linear simples e múltipla.

\section{Resultados}

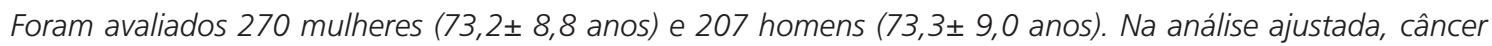
$(\beta=-3,69 ;$ IC95\%=-6,97 a -0,41) e depressão $(\beta=-1,65 ;$ IC95\% $=-3,20$ a $-0,10)$ foram associados à menor força de preensão manual nas mulheres. Para os homens, diabetes ( $\beta=-5,30 ;$ IC95\%=-9, 64 a -0,95), doença pulmonar $(\beta=-4,74$; IC95\%=-7,98 a -1,50) e doença coronariana $(\beta=-3,07$; IC95\%=-5, 98 a $-0,16)$ foram associados a menor força de preensão manual. Houve tendência inversa entre número de doenças e força de preensão manual apenas para os homens.

\section{Conclusão}

Os resultados mostraram associação independente entre doenças crônicas e força de preensão manual. Sendo assim, a força de preensão manual é uma medida válida para ser utilizada na prevenção ou na intervenção das doenças crônicas e nas multimorbidades.

Palavras-chave: Envelhecimento. Doença crônica. Força da mão.

\section{INTRODUCTION}

The multimorbidity or simultaneous presence of disease of cognitive and physical functional limitations ${ }^{1}$ is a common problem in older adults. In Brazil, data from the 2003 Brazilian National Household Sample Survey showed that $75.5 \%$ of Brazilian older adults had at least one chronic disease and $64.4 \%$ had more than one disease ${ }^{2}$.

In older adults, the presence of chronic diseases is associated with a reduction in muscle strength $^{3}$. It is suggested that multimorbidity may create synergistic interactions between the diseases, increasing the risk of reduced muscle strength ${ }^{4}$. The mechanisms underlying this relationship are still unclear. Nutritional depletion, reduced physical activity, and inflammatory condition $^{5}$ are some of the potential factors that mediate this relationship.

Handgrip strength is a tool that is used in both a clinical and epidemiological context ${ }^{4,6}$. It is a non-invasive, easy to use, and low cost method for checking muscle function, with predictive potential for the occurrence of chronic diseases ${ }^{3}$. The handgrip strength is nutritional status indicator $^{6}$, a surrogate measurement of overall 
muscular strength 7 , and can be used for nutritional risk assessment in hospitals ${ }^{6}$ and in health surveillance ${ }^{4}$.

In Brazil, there are no population studies that have assessed chronic disease, multimorbidity, and handgrip strength in older adults. However, the assumptions about these factors as predictors of disability ${ }^{8}$, disease severity, and mortality ${ }^{9}$ indicate the importance of this research for the development of public policies that strengthen health services. Thus, the aim of this study was to investigate the association between chronic disease, multimorbidity, and handgrip strength in a community dwelling older adults from Southern Brazil.

\section{METHODS}

This is epidemiological cross-sectional study based on data from a population and household-based survey ("Effectiveness of health actions, physical activity and nutrition among older adults of the municipality of Antônio Carlos, Santa Catarina"). The survey was carried out in 2010 and 2011 in the city of Antônio Carlos in Southern Brazil.

In 2010, Antônio Carlos had 7,458 inhabitants, of which 914 (12.3\%) were aged 60 or older. Approximately $70.0 \%$ of the population lived on small farms. The human development index of the municipality was 0.749 and electricity reached $100.0 \%$ of households. Of all households, $29.4 \%$ had water plumbing, $52.8 \%$ had access to water through a well or spring on their property, and $17.8 \%$ accessed water in other ways ${ }^{10}$. Access to primary health care is performed by a basic health unit and three teams (composed of a doctor, nurse, nursing assistants, and community health workers) of the Family Health Program, which attended to the entire population of the county.

Details of the sample and population were previously published ${ }^{11}$ and will be briefly described. The population consisted of all persons aged 60 years or older (rural and urban) who were registered at Family Health Program $(n=917)$ in 2009. For older adults (60-79 years) the sample consisted of 343 individuals (error margin of $5.4 \%$, prevalence of $50.0 \%$ for unknown outcome, power test of $80.0 \%$ and sample loss of $15.0 \%$ ) selected by probability sampling, stratified by Family Health Program area. All individuals aged 80 years and over were interviewed $(n=134)$. Exclusion criteria were lack of an appropriate informant, inability to reach older adults after three attempts on alternate days, and lack of access to the residences because of the conditions of the rural roads.

Data were collected during a home visit by trained interviewers. For the collection of data, a form based on the questionnaire of the Saúde, Bem-Estar e Envelhecimento (SABE, Well-Being, and Aging) survey was used. The SABE survey was conducted in seven cities/countries in Latin America and the Caribbean, including São Paulo/Brasil ${ }^{12}$.

The research Protocol $n^{\circ} 189 / 09$ was approved by the Ethics Committee on Research in Human Beings from the Universidade Federal de Santa Catarina.

The independent variables of the study were self-reported chronic diseases and history of falls in the previous year. The occurrence of chronic diseases (yes/no) was identified through the following question: "Has a doctor or nurse ever told you that you have..." (hypertension, diabetes, cancer, chronic lung diseases, coronary heart disease, cerebrovascular disease, arthritis/ rheumatism/arthrosis, and depression). The occurrence of falls (yes/no) was measured by the question: "Did you fall in the past 12 months?".

The handgrip strength (dependent variable) was measured by a mechanical Dynamometer (Takei Kiki Kogyio - TK 1201, Japan), adjusted according to individual hand size. The test was applied to the dominant hand as indicated by each participant.

Adjustment variables were age, literacy (both reading and writing [yes, no]), living 
arrangements (lives alone/lives accompanied), smoking habits (never, former, and current). Body Mass Index (BMI) was obtained from body mass and height (BMI=body mass/[height]2), which were measured by standard procedures ${ }^{13}$. When interviewees were unable to obtain body mass or height measurements $(n=9)$ equations to estimate body mass $^{13}$ and height ${ }^{14}$ were used. Cognitive function (normal/altered) was assessed using the Mini-Mental State Examination (MMSE), according to Bertolucci et al..$^{15}$ criteria: $\leq 12$ points, altered.

Means, standard deviations, and proportions were used for descriptive analysis. Determination of the differences between means was made using the Student's $t$ test (continuous variables) and the Chi-square test (categorical variables).

Simple and multiple linear regression and 95\% Confidence Intervals $(95 \% \mathrm{Cl})$ verified the association between various chronic diseases and handgrip strength. We considered three regression models for chronic disease and handgrip strength association: 1) adjusted by age, literacy, and living arrangements; 2) adjusted by age, literacy, living arrangement, smoking habits, BMI, and cognitive function, 3) elimination of the possible confounding effect of comorbidities by adjusting the final model for all other chronic diseases. Among the adjustment variables, age and BMI were entered in the models as continuous variables and the others were entered as categorical variables.

In the trend analysis between the mean handgrip strength values ( $\mathrm{kg} /$ force) and number of chronic diseases, we used multiple linear regression adjusted for age, literacy, living arrangement, smoking, $\mathrm{BMI}$, and cognitive function.

In all analyses, a significance level of 5\% was used. Data were double entered in Statistical Package for the social Sciences (SPSS Inc., Chicago, Illinois, United States) 16.0 program and the analyses were performed using Stata (Stata Corporation, College Station, Texas, United States) 11.0 software. The analyses were weighted by poststratification weights to account for the sampling design.
RES U L T S

The study sample consisted of 477 older adults ( $73.3 \pm 8.9$ years). Of this population, $3.4 \%$ $(n=16)$ were physically unable to perform the handgrip strength test, and one person (0.2\%) refused to perform the test.

The mean female age was $73.2 \pm 8.9$ years and the mean male age was $73.3 \pm 9.0$ years. The mean handgrip strength values were higher in men $(32.9 \pm 8.8 \mathrm{~kg} /$ force) than in women $(21.2 \pm 5.8 \mathrm{~kg} /$ force $)$. This difference was significant $(p<0.001)$.

The prevalence of people who could read and write $(87.0 \%)$ and who had never smoked $(92.7 \%)$ was higher in women than in men. Men were more likely to live accompanied (94.4\%). Hypertension, diabetes, arthritis/rheumatism/ arthrosis, depression, osteoporosis, and a history of falls were more prevalent in women than in men (Table 1).

The associations between various chronic diseases and handgrip strength in women and men are shown in Tables 2 and 3, respectively. In the simple analysis, cancer, cerebrovascular disease, and depression were associated with lower handgrip strength in women. When the adjustment variables were added to the model (age, literacy, living arrangement, smoking, BMI, and cognitive function), cancer, cerebrovascular disease and depression remained associated with handgrip strength. In the final model, after adjusting for other chronic diseases, only cancer ( $\beta=-3.69 ; C 195 \%=-6.97$ to $-0.41 ; p=0.028)$ and depression $(\beta=-1.65$; $C 195 \%=-3.20$ to -0.10 ; $p=0.037$ ) remained significant. For these chronic diseases, the handgrip strength was almost $4 \%$ lower when compared to the simple analysis (Table 2).

In men (Table 3), the results of the simple analysis showed that chronic lung disease and coronary heart disease were associated with lower handgrip strength. After adjusting for age, literacy, living arrangement, smoking, BMI, and cognitive function, chronic lung disease and coronary heart disease remained significant, whereas diabetes 
Table 1. Characteristics of the study population, according sex. Antônio Carlos (SC), Brazil (2010-2011).

\begin{tabular}{|c|c|c|c|c|c|}
\hline \multirow{2}{*}{ Characteristics } & \multicolumn{2}{|c|}{ Men $(n=207)$} & \multicolumn{2}{|c|}{ Women $(n=207)$} & \multirow{2}{*}{$p$-value } \\
\hline & $n$ & $\%$ & $n$ & $\%$ & \\
\hline Literacy $^{*}$ & & & & & 0.005 \\
\hline Yes & 158 & 76.2 & 235 & 87.0 & \\
\hline No & 49 & 23.8 & 34 & 13.0 & \\
\hline Living arrangement & & & & & $<0.001$ \\
\hline Lives alone & 13 & 5.6 & 52 & 18.8 & \\
\hline Lives accompanied & 194 & 94.4 & 218 & 81.2 & \\
\hline Smoking & & & & & $<0.001$ \\
\hline Never & 80 & 39.3 & 253 & 92.7 & \\
\hline Former/current & 127 & 60.7 & 17 & 7.3 & \\
\hline Altered cognitive function ${ }^{*}$ & 16 & 6.6 & 39 & 11.9 & 0.056 \\
\hline Disability - basic activities of daily living & 42 & 21.9 & 83 & 29.9 & 0.070 \\
\hline Disability - instrumental activities of daily living ${ }^{*}$ & 72 & 32.9 & 146 & 51.5 & $<0.001$ \\
\hline Hypertension & 124 & 59.1 & 218 & 80.7 & $<0.001$ \\
\hline Diabetes* $^{*}$ & 23 & 12.1 & 66 & 25.2 & 0.001 \\
\hline Cancer & 15 & 7.0 & 10 & 4.1 & 0.191 \\
\hline Chronic lung disease & 24 & 11.6 & 29 & 10.6 & 0.753 \\
\hline Coronary disease* & 58 & 25.9 & 80 & 28.4 & 0.563 \\
\hline Cerebrovascular disease & 17 & 7.6 & 22 & 7.7 & 0.984 \\
\hline Arthritis/rheumatism/arthrosis & 42 & 21.8 & 105 & 40.1 & $<0.001$ \\
\hline Depression* & 53 & 26.9 & 98 & 36.7 & 0.035 \\
\hline Osteoporosis & 8 & 4.1 & 82 & 32.1 & $<0.001$ \\
\hline History of falls & 39 & 15.8 & 87 & 31.4 & $<0.001$ \\
\hline
\end{tabular}

Note: *Dropped data. $p$-value was calculated by Chi-squared test; $p \leq 0,05$ values are in bold.

Table 2. Linear regression analysis (simple and multiple) for each chronic disease and handgrip strength in women ( $\mathrm{n}=262)$. Antônio Carlos (SC), Brazil (2010-2011).

\begin{tabular}{|c|c|c|c|c|c|c|c|c|}
\hline \multirow{2}{*}{ Variables } & \multicolumn{2}{|c|}{ Simple analysis } & \multicolumn{2}{|c|}{ Model 1} & \multicolumn{2}{|c|}{ Model 2} & \multicolumn{2}{|c|}{ Model 3} \\
\hline & $\beta$ & $95 \% \mathrm{Cl}$ & $\beta$ & $95 \% \mathrm{Cl}$ & $\beta$ & $95 \% \mathrm{Cl}$ & $\beta$ & $95 \% \mathrm{Cl}$ \\
\hline Hypertension & 0.74 & $-1.07 ; 2.55$ & 0.82 & $-0.99 ; 2.63$ & 0.25 & $-1.71 ; 2.21$ & 1.00 & $-2.05 ; 2.25$ \\
\hline Diabetes & -1.02 & $-2.78 ; 0.73$ & -1.01 & $-2.74 ; 0.73$ & -1.22 & $-3.00 ; 0.56$ & -1.42 & $-3.27 ; 0.44$ \\
\hline Cancer & -3.67 & $-6.78 ;-0.56$ & -3.52 & $-7.11 ; 0.08$ & -3.47 & $-6.96 ; 0.03$ & -3.69 & $-6.97 ;-0.41$ \\
\hline Chronic lung disease & 1.22 & $-1.65 ; 4.10$ & 1.08 & $-1.76 ; 3.93$ & 0.99 & $-1.82 ; 3.80$ & 1.86 & $-0.84 ; 4.55$ \\
\hline Coronary disease & -0.37 & $-1.93 ; 1.19$ & -0.13 & $-1.65 ; 1.40$ & -0.29 & $-1.80 ; 1.23$ & 0.92 & $-0.56 ; 2.40$ \\
\hline Cerebrovascular disease & -3.55 & $-6.43 ;-0.66$ & -3.68 & $-6.89 ;-0.46$ & -3.51 & $-6.82 ;-0.21$ & -3.12 & $-6.52 ; 0.28$ \\
\hline Arthritis/heumatism/arthrosis & -0.63 & $-2.16 ; 0.89$ & -0.82 & $-2.30 ; 0.65$ & -0.87 & $-2.38 ; 0.64$ & -0.26 & $-1.82 ; 1.29$ \\
\hline Depression & -1.56 & $-3.11 ;-0.02$ & -1.87 & $-3.37 ;-0.37$ & -1.79 & $-3.29 ;-0.29$ & -1.65 & $-3.20 ;-0.10$ \\
\hline Osteoporosis & -0.96 & $-2.55 ; 0.63$ & -0.67 & $-2.24 ; 0.90$ & -0.73 & $-2.32 ; 0.85$ & -0.40 & $-2.18 ; 1.37$ \\
\hline History of falls & -1.47 & $-3.10 ; 0.17$ & -1.01 & $-2.64 ; 0.63$ & -1.24 & $-2.86 ; 0.37$ & 0.95 & $-2.63 ; 0.72$ \\
\hline
\end{tabular}

Note: Values in bold are statistically significant $(p \leq 0.05)$.

Model 1: Age, literacy, living arrangement; Model 2: Age, literacy, living arrangement, smoking habits, nutritional status (body mass index), cognitive function; Model 3: Ajusted for all the previous variables and other chronic diseases.

95\% Cl: $95 \%$ Confidence Interval.

and hypertension also became significant. When adjusting for other chronic diseases (model 3 ), diabetes $(\beta=-5.30 ; C 195 \%=-9.64$ to -0.95 ; $p=0.017)$, chronic lung disease $(\beta=-4.74$;
$\mathrm{C} 195 \%=-7.98$ to $-1.50 ; p=0.004)$, and coronary heart disease $(\beta=-3.07$; $C 195 \%=-5.98$ to -0.16 ; $p=0.039$ ) remained associated with lower handgrip strength (Table 3). 
Table 3. Linear regression analysis (simple and multiple) for each chronic disease and handgrip strength in men ( $n=196)$. Antônio Carlos (SC), Brazil (2010-2011).

\begin{tabular}{|c|c|c|c|c|c|c|c|c|}
\hline \multirow{2}{*}{ Variables } & \multicolumn{2}{|c|}{ Simple analysis } & \multicolumn{2}{|c|}{ Model 1} & \multicolumn{2}{|c|}{ Model 2} & \multicolumn{2}{|c|}{ Model 3} \\
\hline & $\beta$ & $95 \% \mathrm{Cl}$ & $\beta$ & $95 \% \mathrm{Cl}$ & $\beta$ & $95 \% \mathrm{Cl}$ & $\beta$ & $95 \% \mathrm{Cl}$ \\
\hline Hypertension & -2.06 & $-4.65 ; 0.53$ & -2.04 & $-4.19 ; 0.11$ & -2.48 & $-4.75 ;-0.20$ & -1.75 & $-3.95 ; 0.44$ \\
\hline Diabetes & -3.16 & $-8.21 ; 1.89$ & -4.81 & $-9.27 ;-0.34$ & -5.39 & $-9.88 ;-0.89$ & -5.30 & $-9.64 ;-0.95$ \\
\hline Cancer & 0.05 & $-4.04 ; 4.14$ & -1.60 & $-4.71 ; 1.51$ & -1.56 & $-4.81 ; 1.68$ & -1.22 & $-4.57 ; 2.13$ \\
\hline Chronic lung disease & -6.21 & $-9.23 ;-3.20$ & -3.38 & $-6.34 ;-0.42$ & -3.59 & $-6.60 ;-0.59$ & -4.74 & $-7.98 ;-1.50$ \\
\hline Coronary disease & -4.77 & $-7.95 ;-1.60$ & -3.39 & $-6.53 ;-0.25$ & -3.82 & $-7.02 ;-0.62$ & -3.07 & $-5.98 ;-0.16$ \\
\hline Cerebrovascular disease & -4.35 & $-11.04 ; 2.33$ & -3.65 & $-9.49 ; 2.20$ & -3.68 & $-9.34 ; 2.04$ & -1.02 & $-6.01 ; 3.97$ \\
\hline Arthritis/heumatism/arthrosis & -2.00 & $-5.40 ; 1.40$ & -1.54 & $-4.38 ; 1.29$ & -1.61 & $-4.45 ; 1.23$ & -1.04 & $-4.09 ; 2.00$ \\
\hline Depression & -0.77 & $-4.21 ; 2.67$ & -1.37 & $-4.40 ; 1.66$ & -1.47 & $-4.46 ; 1.52$ & -0.29 & $-2.88 ; 2.29$ \\
\hline Osteoporosis & -2.22 & $-7.82 ; 3.38$ & -2.44 & $-6.45 ; 1.56$ & -1.87 & $-6.38 ; 2.64$ & -3.47 & $-7.86 ; 0.92$ \\
\hline History of falls & -2.82 & $-6.08 ; 0.44$ & -0.21 & $-3.31 ; 2.89$ & -0.24 & $-3.28 ; 2.80$ & -0.68 & $-1.98 ; 3.34$ \\
\hline
\end{tabular}

Note: Values in bold are statistically significant $(p \leq 0.05)$.

Model 1: Age, literacy, living arrangement; Model 2: Age, literacy, living arrangement, smoking habits, nutritional status (body mass index), cognitive function; Model 3: Ajusted for all the previous variables and other chronic diseases.

95\% Cl: 95\% Confidence Interval.

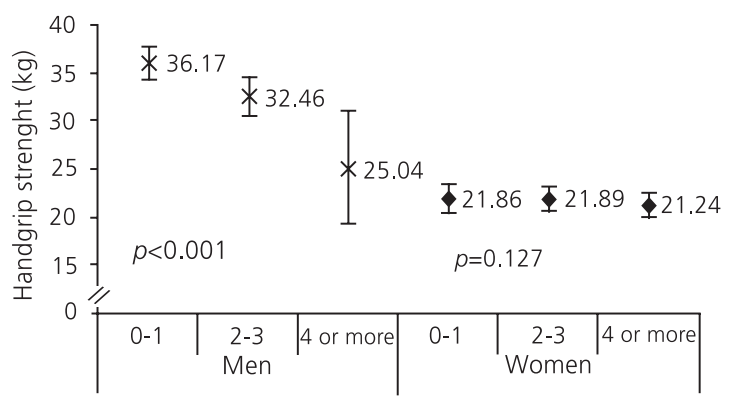

Figure 1. Mean handgrip strength $(\mathrm{kg})$ and number of chronic diseases in men $(n=196)$ and women $(n=292)$ (trend analysis graph). Antônio Carlos (SC), Brazil (2010-2011).

Note: Adjusted analysis for: age, literacy, living arrangement, smoking habits, nutritional status (body mass index), cognitive function. Multiple linear regression analysis.

Figure 1 shows the trend chart for the number of chronic diseases and handgrip strength for men and women. The analysis was adjusted for age, literacy, living arrangement, smoking, $\mathrm{BMI}$, and cognitive function. In men with four or more diseases, the handgrip strength was $4.5 \mathrm{~kg} /$ force smaller compared to those with two to three diseases ( $\beta=-2.26$; $C 195 \%=-4.35$ to -0.17 ). There was an inverse trend between the variables $(\beta=-4.24 ; C 195 \%=-6.34$ to $-2.15 ; p<0.001)$, but only for men.
DISCUSSION

In the present study, the associations between various chronic conditions and lower handgrip strength in men and women were different. Cancer and depression were associated with lower handgrip strength values in women. For men, the diseases associated with handgrip strength were diabetes, chronic lung disease, and coronary heart disease. In addition, the number of coexisting chronic diseases showed a significant inverse trend among men.

The association between cancer and lower handgrip strength values is still controversial. Cheung et al. ${ }^{3}$ and Ihira et al..$^{16}$ did not find an association between handgrip strength and cancer. However, Norman et al. ${ }^{6}$ showed that malnourished cancer patients had a lower handgrip strength. Differences in equipment, assessment protocol, participant selection, primary outcomes, and the disease stage may be responsible for discrepancy between the two study results. It is known that the occurrence of cancer is related to alterations in the metabolism of nutrients and hormonal changes, which can result in cachexia and thus reduced muscle strength ${ }^{17}$. Additionally, in the presence of cancer, subclinical inflammation seems to participate in the mechanisms of muscle strength reduction ${ }^{18}$. 
Some studies ${ }^{19,20}$ showed an association between depression and lower handgrip strength in women, as verified in this present investigation. In contrast, other studies ${ }^{9,21}$ showed no such association. The differences in the results of these studies may be due to the methods used to diagnose depression, variability in the equipment, and the protocol for measuring handgrip strength. Although depression has a multifactorial background, it is known that individuals with depression may have high concentrations of proinflammatory cytokines Tumor Necrosis Factor - alpha (TNF- $\alpha$ ) and interleukin 622, which have an impact on reduced muscle strength. In addition, people with depression may feel less motivated to perform the test.

The association between handgrip strength and diabetes in men is consistent with previous studies $^{23,24}$. Insulin resistance can have an effect on muscle weakness and produce a subsequent reduction in muscle strength ${ }^{25}$. In the Stenholm et al. ${ }^{26}$ study, long-term exposure to obesity was associated with lower handgrip strength later in life. Stenholm et al. ${ }^{26}$ suggested that this decrease in strength can be indicative of inflammation and alterations in glucose metabolism. However, Cheung et al. ${ }^{3}$ found no association between diabetes and handgrip strength. The divergence between studies may be due to methodological differences.

This study's results showed that coronary heart disease was associated with handgrip strength in males, as shown previously ${ }^{27}$. In a cohort study with 24.4 year follow-up ${ }^{27}$ that evaluated 1,145,467 men, handgrip strength was the best predictor for coronary heart disease. According to Artero et al. ${ }^{28}$, lower insulin resistance, reduced chronic inflammation, lower body weight, and abdominal adiposity are some mechanisms by which muscle strength can improve the prognosis of coronary heart disease.

The observed association between chronic lung disease and lower handgrip strength in men is consistent with the literature ${ }^{4,29}$. Muscle weakness appears to be a common problem in patients with chronic lung disease. Impaired physical condition as caused by chronic inactivity can be an important factor in the loss of muscle mass and strength. Some mechanisms that explain the effect of chronic lung disease on muscle mass are systemic hypoxia and increased levels of proinflammatory cytokines (i.e., interleukin 6, TNF- $\alpha$, and C-reactive protein $)^{30}$.

The negative relationship between the number of comorbid conditions and handgrip strength has also been identified in previous studies $^{3,4}$. It is believed that there may be synergistic interactions between chronic diseases, which can increase the risk of strength decline. Even though fragility was not been evaluated in the present study, handgrip strength is an important criterion for the definition of this condition ${ }^{31}$. Both handgrip strength ${ }^{3}$ and fragility ${ }^{31}$ are associated with multimorbidity, enhancing the relationship between chronic diseases and muscle function. The exact contribution of multimorbidity in reduced muscle strength still requires investigation. Further studies are required to investigate the set of diseases that may predispose the elderly declining muscle strength and function ${ }^{4}$.

The results showed that the chronic conditions associated with lower handgrip strength in men and women were different; Cheung et al. ${ }^{3}$ found similar results. Physiological factors, especially those related to sex hormones, may explain this difference. These factors have mechanisms that are specific to each sex and may have different effects on handgrip strength in men and women ${ }^{3}$. In addition to biological factors, socioeconomic differences between the sexes have repercussions on the health of older adults ${ }^{32}$. since men and women have differences in health conditions, the identification of specific care needs for each sex allows the development of health actions directed to real needs of older adults.

Study limitations include the cross-sectional design and the use of self-reported information. The instrument used to collect information on chronic diseases did not allow for the investigation 
of disease stage, type, or severity of the diseases. Study strengths include the fact that this was the first Brazilian study to investigate the association between chronic various diseases, multimorbidity, and handgrip strength in older adults. The use of a representative sample of older adults from the municipality ensured the study's external validity. In the future, longitudinal studies are needed to identify possible changes in muscle strength and handgrip strength in older adults with chronic diseases and multimorbidity.

\section{CONCLUSION}

The results of this study indicate the association between various chronic diseases, multimorbidity, and handgrip strength differs by sex. In women, cancer and depression are associated with lower handgrip strength. In men, diminished handgrip strength was associated with coronary heart disease and chronic lung disease. For men, there was an inverse trend between the number of chronic diseases and handgrip strength. Thus, handgrip strength is a valid measure for use in prevention and intervention of chronic diseases and multimorbidity. In addition, differences between men and women show the importance of tailoring healthcare programs by gender, since the profile of the decline in muscle strength, as well as chronic diseases, differs between the sexes.

\section{ACKNOWLEDGEMENTS}

The Conselho Nacional de Desenvolvimento Científico e Tecnológico for financing the research. They also thank the Coordenação de Aperfeiçoamento de Pessoal de Ensino Superior for granting the Master scholarship to Júlia Pessini.

\section{CONTRIBUTORS}

J PESSINI contributed to the study design, literature review, data analysis, interpretation of the results, and drafting the manuscript. AR BARBOSA contributed to the study conception, data collection, interpretation of the results, and critical review of the manuscript. EBSM TRINDADE contributed to the study design and literature review. All authors approved the final version of the manuscript.

\section{REFERE N CE S}

1. Marengoni A, Angleman S, Melis R, Mangialasche F, Karp A, Garmen A, et al. Aging with multimorbidity: A systematic review of the literature. Ageing Res Rev. 2011; 10(4):430-9. http://dx.doi.org/10.1016/ j.arr.2011.03.003

2. Instituto Brasileiro de Geografia e Estatística. Sobre as condições de saúde nos idosos: indicadores selecionados. Indicadores sociodemográficos e de saúde no Brasil. Brasília: IBGE; 2009 [acesso 2014 jun 10]. Disponível em: http://www.ibge.gov.br/ home/estatistica/populacao/indicsociosaude/2009/ comsobre.pdf

3. Cheung CL, Nguyen US, Au E, Tan KC, Kung AW. Association of handgrip strength with chronic diseases and multimorbidity: A cross-sectional study. Age. 2013; 35(3):929-41. http://dx.doi.org/ 10.1007/s11357-012-9385-y

4. Stenholm S, Tiainen K, Rantanen T, Sainio P, Hellovaara M, Impivaara $O$, et al. Long-term determinants of muscle strength decline: Prospective evidence from the 22-year mini-Finland follow-up survey. J Am Geriatr Soc. 2012; 60(1):77-85. http://dx.doi.org/10.1111/j.1532-5415.2011.03 779.x

5. Rantanen T, Volpato S, Ferrucci L, Heikkinen E, Fried LP, Guralnik JM. Handgrip strength and causespecific and total mortality in older disabled women: Exploring the mechanism. J Am Geriatr Soc. 2003; 51(5):636-41. http://dx.doi.org/10. 1034/j.1600-0579.2003.00207.x

6. Norman K, Stobaus N, Smoliner C, Zocher D, Scheufele R, Valentini L, et al. Determinants of hand grip strength, knee extension and functional status in cancer patients. Clin Nutr. 2010; 29(5):586-91. http://dx.doi.org/10.1016/j.clnu.2010.02.007

7. Ling CH, Taekema D, Craen AJ, Gussekloo J, Westendorp RG, Maier AB. Handgrip strength and mortality in the oldest old population: The Leiden 85-plus study. CMAJ. 2010; 182(5):429-35. http:// dx. doi.org/10.1503/cmaj.091278

8. Douglass CW, Shanmugham JR. Primary care, the dental profession, and the prevalence of chronic diseases in the United States. Dent Clin North Am. 2012; 56(4):699-730. http://dx.doi.org/10.1016/ j.cden.2012.07.002 
9. Taekema DG, Gussekloo J, Maier AB, Westendorp RG, Craen AJ. Handgrip strength as a predictor or functional, psychological and social health: A prospective population-based study among oldest old. Age Aging. 2010; 39(3):331-7. http://dx.doi. org/10.1093/ageing/afq022

10. Instituto Brasileiro de Geografia e Estatística. Censo demográfico. IBGE cidades. Brasília: IBGE; 2014 [acesso 2014 mar 23]. Disponível em: http://www. ibge.gov.br/cidadesat

11. Confortin SC, Barbosa AR, Danielewicz AL, Meneghini V, Testa WL. Desempenho motor de idosos de uma comunidade do sul do Brasil. Rev Bras Cineantropom Desempenho Hum. 2013; 15(4):417-42. http://dx.doi.org/10.5007/1980-0 037.2013v15n4p417

12. Lebrão ML, Laurenti R. Health, well-being and aging: The SABE Study in São Paulo, Brazil. Rev Bras Epidemiol. 2005; 8(2):127-41. http://dx.doi. org/10.1590/S1415-790X2005000200005

13. Chumlea WC, Guo S, Roche AF, Steinbaugh ML. Prediction of body weight for the nonambulatory elderly from anthropometry. J Am Diet Assoc. 1988; 88(5):564-8.

14. Chumlea WC, Roche AF, Mukherjee D. Nutritional assessment of the elderly through anthropometry. Ohio: Wright State University School of Medicine; 1987

15. Bertolucci PHF, Brucki SMD, Capacci SR, Juliano Y. The Mini-Mental State Examination in an outpatient population: Influence of literacy. Arq NeuroPsiquiatr. 1994; 52(1):1-7. http://dx.doi.org/10. 1590/S0004-282X1994000100001

16. Ihira H, Mizumoto A, Makino K, Yasuda K, Yoko Y, Saitoh S, et al. Physica Funtions, health-related outcomes, nutritional status, and blood markers in community-dewlling cancer survivors aged 75 years and older. Asian Pac J Cancer Prev. 2014; 15(7):3305-10. http://dx.doi.org/10.7314/APJCP.20 14.15.7.3305

17. Lenk K, Schuler G, Adams V. Skeletal muscle wasting in cachexia and sarcopenia: Molecular pathophysiology and impact of exercise training. J Cachexia Sarcopenia Muscle. 2010; 1(1):9-21. http://dx.doi.org/10.1007/s13539-010-0007-1

18. Alemán H, Esparza J, Ramirez FA, Astiazaran H, Payette $\mathrm{H}$. Longitudinal evidence on the association between interleikin- 6 and C-reative protein with the loss of total appendicular skeletal muscle in freeliving older men and women. Age Ageing. 2011; 40(4):469-75. http://dx.doi.org/10.1093/ageing/ afr040

19. Castaneda-Sceppa C, Price LL, Noel SE, Bassett Midle J, Falcon LM, Tucker KL. Physical function and health status in aging Puerto Rican adults: The Boston Pueto Rican Health Study. J Aging Health. 2010; 22(5):653-72. http://dx.doi.org/10.1177/08 98264310366738

20. Phillips HJ, Biland J, Costa R, Souverain R. Fiveposition grip strength measures in individuals with clinical depression. J Orthop Sports Phys Ther. 2011; 41(3):149-54. http://dx.doi.org/10.2519/jospt.20 11.3328

21. Lee JE, Kim KW, Paik NJ, Jang HC, Chang CB, Baek $\mathrm{GH}$, et al. Evaluation of factors influencing grip strength in elderly Koreans. J Bone Metab. 2012; 19(2):103-10. http://dx.doi.org/10.11005/jbm.20 12.19.2.103

22. Dowlati Y, Herrmann N, Swardfager W, Liu H, Sham $\mathrm{L}$, Reim EK, et al. A meta-analysis of cytokines in major depression. Biol Psychiatry. 2010; 67(5):446-57. http://dx.doi.org/10.1016/j.biopsych.2009.09.033

23. Wander PL, Boyko EJ, Leonetti DL, McNeely MJ, Kahn SE, Fujimoto WY. Greater hand-grip strength predicts a lower risk of developing type 2 diabetes over 10 years in leaner Japanese Americans. Diabetes Res Clin Pract. 2011; 92(2):261-4. http:// dx.doi.org/10.1016/j.diabres.2011.01.007

24. Leenders $M$, Verdijk LB, van der Hoeven $L$, Adam $J$ J, van Kranenburg J, Nilwik R, et al. Patients with type 2 diabetes show a greater decline in muscle mass, muscle strength, and functional capacity with aging. J Am Med Dir Assoc. 2013; 14(8):585-92. http://dx.doi.org/10.1016/j.jamda.2013.02.006

25. Barzilay Jl, Cotsonis GA, Walston J, Schwartz AV, Satterfield S, Miljkovic I, et al. Insulin resistance is associated with decreased quadriceps muscle strength in nondiabetic adults aged $\geq 70$ years. Diabetes Care. 2009; 32(4):736-8. http://dx.doi. org/10.2337/dc08-1781

26. Stenholm S, Sallinen J, Koster A, Rantanen T, Sainio P, Heliovaara $M$, et al. Association between obesity history and hand grip strength in older adultsexploring the roles of inflammation and insulin resistance as mediating factors. J Gerontol A Biol Sci Med Sci. 2011; 66(3):341-8. http://dx.doi.org/ 10.1093/gerona/glq226

27. Silventoinen K, Magnusson PK, Tynelius P, Batty GD, Rasmussen F. Association of body size and muscle strength with incidence of coronary heart disease and cerebrovascular diseases: A population-based cohort study of one million Swedish men. Int J Epidemiol. 2009; 38(1):110-8. http://dx.doi.org/ 10.1093/ije/dyn231

28. Artero EG, Lee DC, Lavie CJ, España-Romero V, Sui $X$, Church TS, et al. Effects of muscular strength on cardiovascular risk factors and prognosis. J 
Cardiopulm Rehabil Prev. 2012; 32(6):351-8. http:// dx.doi.org/10.1097/HCR.0b013e3182642688

29. Ansari K, Keaney N, Taylor I, Burns G, Farrow M. Muscle weakness, health status and frequency of exacerbations in chronic obstructive pulmonary disease. Postgrad Med J. 2012; 88(1041):372-6. http://dx.doi.org/10.1136/postgradmedj-2011-13 0293

30. O'Shea SD, Taylor NF, Paratz J. Peripheral muscle strength training in COPD: A systematic review. Chest. 2004; 126(3):903-14. http://dx.doi.org/10. 1378/chest.126.3.903
31. Fried LP, Tangen CM, Walston J, Newman AB, Hirsch C, Gottdiener J, et al. Frailty in older adults: Evidence for a phenotype. J Gerontol A Biol Sci Med Sci. 2001; 56(3):M146-56. http://dx.doi.org/10.1093/ gerona/56.3.M146

32. Vlassoff C. Gender differences in determinants and consequences of health and illness. J Health Popul Nutr. 2007; 25(1):47-61.

Received: March 26, 2015

Final version: August 20, 2015

Approved: September 21, 2015 